\title{
TINGKAT KESEPIAN DENGAN DEPRESI PADA LANSIA DI DUKUH TRAYEMAN, BANTUL, YOGYAKARTA
}

\author{
Eliyana \\ Fakultas Kedokteran Universitas Islam Indonesia \\ Jl. Kaliurang KM 14,5, Krawitan, Umbulmartani, Ngemplak, \\ Kabupaten Sleman, Daerah Istimewa Yogyakarta, 55584, Indonesia \\ *)E-mail: ely_pras@yahoo.com
}

Dikirim: Maret 2017, diterbitkan: April 2017

\begin{abstract}
ABSTRAK
Tujuan penelitian: Penelitian ini dilakukan untuk dapat mengetahui hubungan antara tingkat kesepian dan tingkat depresi pada lansia di Dukuh Trayeman, Pleret, Bantul, Yogyakarta. Metode: Desain penelitian deskriptf korelasi dengan menggunakan pendekatan cross sectional digunakan dalam penelitian ini. Pemilihan responden dilakukan menggunakan non-probability sampling dengan teknik purposive sampling sehingga didapatkan 50 responden dengan usia di atas 60 tahun dan tinggal di komunitas. Pengambilan data dilakukan secara langsung sejak tanggal 2-16Agustus 2016 dengan menggunakan kuesioner University California of Los Angeles Loneliness Scale dan Geriatric Depression Scale. Analisis data menggunakan uji korelasi Kendal Tau. Hasil: Penelitian ini menunjukkan ada hubungan yang signifikan antara tingkat kesepian dan tingkat depresi pada lansia di Dukuh Trayeman, Pleret, Bantul, Yogyakarta dengan $p=0,001$ di mana nilai korelasi mencapai 0,892 . Hal ini bermakna terdapat hubungan yang sangat kuat dengan arah positif di antara kedua variabel. Diskusi: Pada masa lanjut usia akan terjadi banyak kemunduran, baik fisik maupun psikologis. Beberapa kemunduran psikologis yang terjadi seperti kesepian dan depresi yang dapat memicu terjadinya penyakit yang kompleks apabila tidak segera diatasi. Kesimpulan: Tingkat kesepian pada lansia merupakan hal yang sangat berkaitan dengan kejadian depresi pada lansia. Maka dari itu, sedini mungkin tingkat kesepian yang terjadi pada lansia harus segera diatasi karena semakin tinggi tingkat kesepian yang dialami oleh lansia, semakin tinggi juga tingkat depresi yang akan terjadi.
\end{abstract}

Kata Kunci: kesepian, depresi, lansia, komunitas.

\section{CORRELATION BETWEEN LONELINESS LEVEL AND DEPRESI IN THE ELDERLY AT TRAYEMAN HAMLET, BANTUL, YOGYAKARTA ABSTRACT}

Objective: This research was conducted to identify the correlation between loneliness level and depression level in the elderly at Trayeman Hamlet, Pleret, Bantul, Yogyakarta. Methods: This study is descriptive correlational by using cross sectional approach. Samples were taken using non-probability sampling with purposive sampling technique with a sample size of 50 respondents aged above 60 years and living in the community. Data were collected directly from 2 August 2016 until 16 August 2016 using University California of Los Angeles Loneliness Scale and Geriatric Depression Scale. The data were analyzed using Kendal's Tau correlation test. Results: This study showed that there was a significant correlation between loneliness level and depression level in the elderly at Trayeman Hamlet, Pleret, Bantul, Yogyakarta with $p=$ $<0.001$ where the correlation value was 0.892. This means there was a very strong correlation with positive direction between the two variables. Discussion: The elderly will experience significant setbacks, either physical and psychological. The psychological setbacks include loneliness and depression which can lead to complex diseases, unless they are addressed immediately. Conclusion: Loneliness level in the elderly is strongly correlated with depression in elderly. Therefore, the loneliness level in the elderly should be addressed as early as possible because the higher the loneliness level experienced by the elderly, the higher the of depression level will occur. 
Keywords: loneliness, depression, elderly, community.

\section{LATAR BELAKANG}

Saat ini lansia merupakan penduduk dengan jumlah perkembangan yang cukup besar. Secara umum, populasi penduduk usia 60 tahun ke atas di negara maju pada tahun 2012 adalah $20 \%$ dari total jumlah penduduk dan diperkirakan meningkat menjadi 32\% pada tahun 2050. Sementara itu, di negara berkembang, jumlah penduduk usia 60 tahun 2012 adalah $15 \%$ dari total jumlah penduduk dan diperkirakan meningkat menjadi 20\% antara 2015-2050 (Pusat Data dan Informasi Kementerian Kesehatan [Kemenkes] RI, 2013).

Jumlah lansia di Indonesia mengalami peningkatan sebesar $7,4 \%$ pada tahun 2013 dan diprediksikan akan mengalami peningkatan $11,4 \%$ pada tahun 2020 . Pada tahun 2014 meningkat menjadi 9,77\%, diprediksikan pada tahun 2020 menjadi 11,34\% (Kemenkes RI, 2016). Usia harapan hidup (UHH) tertinggi dicapai oleh Daerah Istimewa Yogyakarta (DIY) tahun 2015 (Kemenkes RI, 2016). Faktor psikososial lanjut usia (lansia) merupakan permasalahan yang sangat membebani kehidupannya dan pada akhirnya berpengaruh terhadap gangguan fisik, sosial, dan mentalnya. Peningkatan usia harapan hidup tentunya mempunyai dampak lebih banyak terjadinya gangguan penyakit pada lansia (Pudjiastusi, 2013).

Seiring meningkatnya jumlah lansia, angka kesepian pun semakin semakin besar, diperkirakan $50 \%$ lansia kini menderita kesepian. Kondisi lanjut usia yang mengalami berbagai penurunan atau kemunduran baik fungsi biologis maupun psikis dapat mempengaruhi mobilitas dan juga kontak sosial, salah satunya adalah rasa kesepian (loneliness). Lansia yang mengalami kesepian seringkali merasa jenuh dan bosan dengan hidupnya, sehingga dirinya berharap agar kematian segera datang menjemputnya. Hal itu karena dirinya tidak ingin menyusahkan keluarga dan orang-orang disekitarnya (Septiningsih \& Na'imah, 2012).

Gangguan depresi yang sering dijumpai pada lansia merupakan masalah psikososiogeriatri dan perlu mendapat perhatian khusus. Depresi pada lansia kadang-kadang tidak terdiagnosis dan tidak mendapatkan penanganan yang semestinya karena gejala-gejala yang muncul sering kali dianggap sebagai suatu bagian dari proses penuaan yang normal. Prevalensi depresi pada lansia adalah $15,9 \%$, pada tahun 2020 di negara berkembang akan menggantikan penyakit-penyakit infeksi sebagai urutan teratas (Irawan, 2013).

Kesepian terjadi saat klien terpisah dari orang lain dan mengalami gangguan sosial. Dalam banyak kasus, kesepian menyebabkan kesehatan fisik dan mental mengalami penekanan karena mereka tidak mempunyai teman berbelanja dan makan bersama (Sanjaya \& Rusdi, 2013). Kebutuhan untuk berinteraksi dengan orang lain akan dimiliki oleh individu sampai akhir hayat. Namun, sebagian dari individu masih merasa kesepian ketika tidak memiliki lawan interaksi untuk berbagi masalah (Basuki, 2015).

Gangguan depresi ditemukan kira-kira $25 \%$ pada lanjut usia yang ada di komunitas. Tingginya stressor dan peristiwa-peristiwa kehidupan yang tidak menyenangkan dapat menimbulkan kemungkinan lanjut usia mengalami kecemasan, kesepian, sampai pada tahap depresi (Kurniasari, 2014).

Lansia yang tinggal di panti sosial lebih berisiko mengalami depresi karena berada di lingkungan keluarga dan masyarakat yang mengakibatkan lansia lebih banyak 
merasa rendah diri, muncul perasaan tidak berdaya meskipun lansia yang tinggal dengan keluarga juga mungkin mengalami kesepian (Damayanti \& Sukmono, 2015). Kesepian yang dialami oleh lansia sangat berisiko terjadinya depresi karena kesepian merupakan faktor yang dapat memicu tandatanda dan gejala dari depresi (Wu \& Zhang, 2011).

Bantul merupakan salah satu kabupaten di Daerah Istimewa Yogyakarta. Berdasarkan data Badan Pusat Statistik Kabupaten Bantul (2015), jumlah lansia mencapai 120 ribu orang dengan $38 \%$ lansia berada di wilayah Kecamatan Pleret. Data menunjukkan bahwa jumlah lansia tertinggi terdapat di Desa Pleret dengan 11 dukuh, salah satunya Trayeman. Pedukuhan Trayeman memiliki jumlah lansia cukup banyak, yakni 89 orang. Trayeman memiliki posyandu lansia dengan 5 orang kader, tetapi belum berjalan efektif. Berdasarkan wawancara dengan kader, didapatkan bahwa hanya sekitar 30 lansia yang rutin mengikuti posyandu.

Berdasarkan hasil observasi dan wawancara dengan beberapa kader lansia, didapatkan informasi bahwa lansia yang tinggal di Dukuh Trayeman kurang aktif terlibat dalam kegiatan sosial karena merasa sudah tidak pantas dan malu untuk berkumpul dengan warga lainnya. Bahkan, keterlibatan dalam kegiatan posyandu lansia masih sangat minim. Hal ini disebabkan lansia merasa malas dan alasan tidak ada keluarga yang mengantar sehingga mereka lebih memilih untuk di rumah saja. Beberapa lansia juga hanya tinggal sendiri karena pasangannya telah meninggal dunia dan anak-anaknya memilih untuk hidup terpisah.

\section{METODE}

Dalam penelitian digunakan deskriptif korelasi dengan pendekatan cross sectional sebagai desain penelitian. Populasi lansia di Dukuh Trayeman sebanyak 89 orang dipilih menggunakan non-probability sampling dengan teknik purposive sehingga didapatkan lansia yang memenuhi kriteria penelitian; berusia di atas 60 tahun, tinggal dengan atau tanpa keluarga, tidak memiliki penyakit kronis, dan tidak sedang menjalani perawatan di rumah sakit. Sejumlah 50 lansia berpartisipasi dalam penelitian ini dengan pengambilan data secara langsung sejak 2-16 Agustus 2016 secara door to door.

Pengambilan data menggunakan dua buah kuesioner yaitu University California of Los Angeles Loneliness Scale untuk mengukur tingkat kesepian yang terdiri atas 20 item pertanyaan yang kemudian akan dijawab oleh lansia sesuai dengan apa yang dialaminya. Lansia diminta untuk menawab setiap pernyataan dengan memilih salah satu di antara keempat jawaban yang dianggap paling tepat atau paling sesuai dengan keadaan diri lansia saat ini. Jawabannya antara lain tidak pernah, jarang, kadangkadang, dan sering. Pernyataan berupa favorable $(1,4,5,6,9,10,15,16,19,20)$ dan unfavorable $(2,3,7,8,11,12,13,14$, 17, 18). Skor total loneliness responden didapatkan dengan menjumlahkan skor ke 20 item dengan Cronbach's alfa 0,98. Tingkat kesepian lalu dikategorikan dengan skor 2049 tingkat rendah, skor 50-59 tingkat sedang dan skor 60-80 tingkat tinggi.

Kuesioner Geriatric Depression Scale yang digunakan untuk mengukur tingkat depresi pada lansia dengan 30 item pertanyaan. Tiap-tiap jawaban bernilai 1 dan 0 . Nilai Cronbach alfa 0,97. Pilihlah jawaban yang paling tepat untuk menggambarkan perasaan lansia selama satu minggu terakhir. Setiap skor jawaban akan dijumlah dan apabila skor yang diperoleh berkisar antara 0-10, berarti terindikasi depresi ringani. Jika skor 11-20 berarti terindikasi depresi sedang. Jika skor 21-30 berarti terindikasi 
depresi berat. Setelah data diambil dan dilakukan analisis uji korelasi menggunakan melalui proses cleaning, editing, dan coding, Kendal Tau.

HASIL

Tabel 1. Distribusi frekuesi karakteristik sosio-demografi lansia di Dukuh Trayeman

\begin{tabular}{lrr}
\hline \multicolumn{1}{c}{ Karakteristik } & Jumlah & \multicolumn{2}{c}{ Persentase } \\
\hline Jenis Kelamin & & \\
Laki-laki & 18 & 36,0 \\
Perempuan & 32 & 64,0 \\
\hline Usia (tahun) & & \\
$70-75$ & 23 & 46,0 \\
$76-80$ & 21 & 42,0 \\
$81-85$ & 4 & 8,0 \\
$86-90$ & 2 & 4,0 \\
Tinggal Serumah & & \\
Sendiri & 8 & 16,0 \\
Anak & 12 & 24,0 \\
Suami/lstri & 11 & 22,0 \\
Keluarga Besar & 19 & 38,0 \\
Pendidikan & & \\
Tidak Sekolah & 12 & 24,0 \\
SD & 19 & 38,0 \\
SMP & 12 & 24,0 \\
SMA & 4 & 8,0 \\
Sarjana & 3 & 6,0 \\
Status Perkawinan & & \\
Tidak menikah & 8 & 16,0 \\
Menikah & 16 & 32,0 \\
Janda/Duda & 26 & 52,0 \\
\hline$\quad$ Total & 50 & 100 \\
\hline
\end{tabular}

Berdasarkan Tabel 1 dapat diidentifikasi Sementara itu, data tentang anggota keluarga bahwa lansia yang berjenis kelamin laki-laki yang tinggal serumah menunjukkan bahwa berjumlah 18 orang dengan persentase $36 \%$ dan lansia yang berjenis kelamin perempuan berjumlah 32 orang dengan persentase $64 \%$. Hal ini menunjukkan bahwa lansia yang berjenis kelamin perempuan lebih banyak dibanding lansia yang berjenis kelamin lakilaki.

Berdasarkan umur, tampak bahwa responden dengan usia 70-75 tahun dan 76-80 tahun menduduki persentase tertinggi. lansia yang tinggal bersama keluarga besar paling banyak dengan persentase $38,0 \%$, sedangkan lansia yang tinggal sendiri sebanyak $16,0 \%$.

Berdasarkan tingkat pendidikan, tampak bahwa lansia yang berpendidikan SD paling banyak dengan persentase $38,0 \%$. Selain itu, sebanyak 26 lansia telah kehilangan pasangan hidupnya.

Tabel 2. Distribusi frekuensi tingkat kesepian lansia di Dukuh Trayeman

\begin{tabular}{lrr}
\hline \multicolumn{1}{c}{ Kriteria } & Jumlah & Persentase \\
\hline Rendah (Skor 20-49) & 4 & 8,0 \\
Sedang (Skor 50-59) & 27 & 54,0 \\
Tinggi (Skor 60-80) & 19 & 38,0 \\
\hline Total & 50 & 100 \\
\hline
\end{tabular}


Berdasarkan Tabel 2 dapat diketahui bahwa tingkat kesepian lansia di Trayeman mayoritas dalam kategori sedang, yaitu terdapat 19 lansia yang memiliki tingkat kesepian tinggi. Hal ini menunjukkan perlu adanya skrining dan penanganan lebih lanjut. sebanyak 54,0\%. Meskipun demikian,

Tabel 3. Distribusi frekuensi tingkat depresi lansia di Dukuh Trayeman

\begin{tabular}{lll}
\hline \multicolumn{1}{c}{ Kriteria } & Jumlah & Persentase \\
\hline Rendah (Skor 0-10) & 0 & 0 \\
Sedang (Skor 11-20) & 29 & 58,0 \\
Tinggi (Skor 21-30) & 21 & 42,0 \\
\hline Total & 50 & 100 \\
\hline
\end{tabular}

Dari Tabel 3 dapat diketahui bahwa sebanyak 29 lansia di dukuh Trayeman mayoritas mengalami depresi dengan kategori sedang. Selain itu, sebanyak 21 yang bisa ditimbulkan akibat depresi.

Tabel 4. Uji korelasi tingkat kesepian dengan depresi pada lansia di Dukuh Trayeman

\begin{tabular}{lll}
\hline \multicolumn{1}{c}{ Variabel } & \multicolumn{1}{c}{$\begin{array}{c}\text { Koefisien } \\
\text { Korelasi } \\
\text { Kendall Tau }\end{array}$} & Probabilitas \\
\hline $\begin{array}{l}\text { Tingkat Kesepian } \\
\text { dengan Depresi }\end{array}$ & 0,858 & 0,000 \\
\hline
\end{tabular}

Berdasarkan Tabel 4 didapatkan bahwa ada hubungan korelasi yang signifikan antara tingkat kesepian dan tingkat depresi yang dialami oleh lansia di Dukuh Trayeman, Pleret, Bantul, Yogyakarta.

\section{DISKUSI}

Hasil penelitian menunjukkan bahwa lansia mengalami kesepian dengan kriteria sedang. Lansia tersebut sudah mengalami kesepian dalam dirinya yang diakibatkan oleh banyak faktor. Kesepian atau loneliness didefinisikan sebagai perasaan kehilangan dan ketidakpuasan yang dihasilkan oleh ketidaksesuaian antara jenis hubungan sosial yang kita inginkan dan jenis hubungan sosial yang kita miliki (Nurhayati, 2016).

Kesepian dapat bersifat kuantitatif seperti tidak memiliki teman atau hanya memiliki teman dalam jumlah sedikit maupun bersifat kualitatif seperti merasa bahwa hubungannya dengan orang lain dangkal atau kurang memuaskan seperti yang diharapkan (Verawati, 2015). Dalam suatu penelitian ditemukan bahwa kesepian diasosiasikan dengan perasaan depresi, rasa cemas, ketidakpuasan, tidak bahagia, dan kesedihan (Sugiyanti, 2010).

Mayoritas lansia tinggal dengan keluarganya, tetapi hal ini tidak berarti ia tidak merasa kesepian. Penelitian sebelumnya oleh Dahlberg \& McKee (2014) menyatakan bahwa masih banyak lansia yang mengalami kesepian meskipun berada di lingkungan keluarga. Hal tersebut dipicu oleh beberapa hal seperti kurangnya dukungan dari keluarga, kurang melibatkan lansia dalam urusan keluarga, serta hubungan yang tidak adekuat antara keluarga. Mekanisme koping lansia yang tidak adekuat akan sangat berpengaruh terhadap kondisi fisik dan psikososial lansia. Apabila hal tersebut tidak segera diatasi, akan timbul gangguan kejiwaan pada lansia. 
Terkait dengan tingkat depresi, menurut hasil penelitian ini, mayoritas lansia mengalami depresi sedang, tetapi hampir dari setengah responden mengalami depresi dengan kriteria tinggi. Gangguan depresi pada umunya dicetuskan oleh peristiwa hidup tertentu. Kenyataannya peristiwa hidup tersebut tidak selalu diikuti oleh depresi. Hal ini mungkin disebabkan oleh adanya faktorfaktor lain yang ikut berperan mengubah atau mempengaruhi hubungan tersebut. Jarang depresi terjadi hanya disebabkan oleh satu faktor saja dan salah satu faktor yang memengaruhi terjadinya depresi ialah rasa kesepian yang dialami oleh lansia yang ditinggal pasangannya (Kurniasari, 2014).

Pada penelitian yang dilakukan oleh Kurniasari (2014), terdapat beberapa faktor lain yang dapat menyebabkan lansia mengalami gangguan mood. Salah satunya usia yang merupakan salah satu faktor yang dapat memengaruhi kesehatan seseorang. Sementara itu, dalam penelitian yang dilakukan oleh Nauli, Yuliatri, \& Savita (2010) didapatkan bahwa depresi merupakan bagian alami dari proses kejiwaan seseorang, apalagi pada usia lanjut.

Tingkat depresi yang terjadi pada lansia cukup tinggi dibandingkan dengan usia lainnya. Hal tersebut disebabkan lansia dengan usia 60 tahun ke atas sudah mengalami banyak sekali kemunduran dari aspek psikologis maupun fisik serta fungsional. Kemunduran tersebut memicu stres dan depresi (Qonitah \& Isfandiari, 2015).

Lansia sangat membutuhkan dukungan keluarga dalam masa atau proses penuaan. Hal ini mendukung penelitian yang dilakukan oleh Sustyani (2012) bahwa adanya dukungan keluarga pada lansia sangat berpengaruh terhadap tingkat depresi yang dialami oleh lansia. Selain itu, menurut Kristiyaningsih (2011), salah satu faktor yang menyebabkan lansia mengalami depresi ialah status perkawinan. Lansia yang ditinggal pasangannya akan terpengaruh status psikologinya dan berdampak terhadap tingkat depresi yang dialaminya.

Keberadaan dukungan dari keluarga juga dikemukakan oleh penelitian Monika (2015) yang menyatakan bahwa lansia yang tinggal di panti sosial atau panti wredha lebih berisiko mengalami depresi karena kondisi yang jauh dari keluarga. Namun, pendapat berbeda disampaikan oleh Setiawan, Budiningsih, \& Andromeda (2013) bahwasanya lansia yang tinggal di rumah justru lebih berisiko mengalami depresi. Hal tersebut disebabkan lansia yang tinggal di rumah berada di antara orang-oramg dan lingkungan yang baik, tetapi dukungan terhadap lansia tersebut tidak ada. Dengan demikian, yang diharapkan oleh lansia tidak sesuai dengan yang didapatkan dari lingkungan keluarganya maupun lingkungan sosial.

Setiawan, Budiningsih, \& Andromeda (2013) berpendapat bahwa kesepian yang dialami oleh lansia akan memunculkan ketidakberdayaan lansia dalam menjalani kehidupannya dan tingkat depresinya semakin tinggi. Ada sejumlah faktor psikososial yang diprediksi sebagai penyebab gangguan mental, salah satunya depresi. Faktor psikososial tersebut ialah hilangnya peranan sosial, hilangnya otonomi, kematian teman atau sanak saudara, penurunan kesehatan, peningkatan isolasi diri, keterbatasan finansial, dan penurunan fungsi kognitif serta berkurangnya dukungan sosial (Sadock \& Sadock, 2004/2010). Penelitian Marta (2012) menyebutkan bahwa faktor psikososial meliputi penurunan percaya diri, kemampuan untuk mengadakan hubungan intim, penurunan jaringan sosial, kesepian, perpisahan, kemiskinan dan penyakit fisik.

Stresor lingkungan yang paling berhubungan dengan onset suatu episode depresi adalah kehilangan pasangan (Sadock 
\& Sadock, 2004/2010). Stresor psikososial yang bersifat akut, seperti kehilangan orang yang dicintai, atau stresor kronis misalnya kekurangan finansial yang berlangsung lama, kesulitan hubungan interpersonal, ancaman keamanan dapat menimbulkan depresi (Aristawati, Ratnawati, \& Imavike, 2015).

Penelitian yang dilakukan oleh Utomo (2013) menemukan bahwa hubungan partisipasi sosial kurang, partisipasi sosial cukup, dan gangguan fungsional sedang dengan kejadian depresi pada lanjut usia. Menurut Burholt \& Scharf (2014) menyebutkan bahwa terjadinya depresi pada lansia dapat disebabkan oleh beberapa faktor seperti gangguan fisik, isolasi sosial dan kesepian, sikap dari lanjut usia, penyangkalan, dan pengabaian terhadap proses penuaan normal.

Hasil penelitian ini menunjukkan bahwa tingkat kesepian memiliki hubungan yang signifikan terhadap kejadian depresi pada lansia. Menurut Darmojo (2011) dalam Pangulu, Rachmawati, \& Suratini (2015) salah satu masalah kesehatan yang muncul pada usia lanjut ialah semakin menurunnya kondisi fisik dan psikologis, semakin tinggi risiko terjadinya depresi pada lansia. Hal ini sangat erat kaitannya dengan kebutuhan lansia untuk bisa berhubungan dengan orang lain. Lansia membutuhkan waktu untuk dapat berinteraksi dan berkomunikasi dengan lingkungan sosialnya agar tidak merasakan kesepian dalam hidupnya (Basuki, 2015). Keduanya saling berkaitan, yakni apabila lansia mengalami kesepian, tingkat depresi akan semakin tinggi.

Anggraini \& Asnindari (2010) menyatakan bahwa kesepian yang dialami oleh lansia akan memunculkan ketidakberdayaan lansia dalam menjalani kehidupannya dan tingkat depresi semakin tinggi. Lansia yang mengalami kesepian dalam hidupnya lambat laun akan mengalami depresi yang berkepanjangan sehingga akan berpengaruh terhadap kesehatannya secara keseluruhan. Perhatian dan peran serta keluarga dan tenaga kesehatan diperlukan untuk membantu lansia menjalani kehidupan yang baik di usia senja.

\section{SIMPULAN}

Berdasarkan penelitian yang dilakukan, didapatkan hasil koefisien korelasi dengan arah positif, yaitu apabila tingkat kesepian semakin tinggi, semakin tinggi juga tingkat depresi yang dialami oleh lansia di Dukuh Trayeman, Pleret, Bantul, Yogyakarta.

\section{DAFTAR PUSTAKA}

Anggraini, R. \& Asnindari, L. N. (2010). Perbedaan tingkat kesepian lanjut usia yang memiliki pasangan hidup dan yang tidak memiliki pasangan hidup di Dusun Kragilan Kelurahan Tamanan Banguntapan Bantul Yogyakarta (Skripsi). STIKES 'Aisyiyah Yogyakarta, Yogyakarta, Indonesia.

Aristawati, E., Ratnawati, R., \& Imavike, F. (2015). Studi Fenomenologi: Pengalaman Kesepian pada Lansia yang Tinggal Seorang Diri di Desa Tunggul Wulung-Pandaan. The Indonesian Journal of Health Sciences, 6(1): 18-25.

Badan Pusat Statistik Bantul. (2015). Bantul dalam Angka 2015. Retrieved from https://bantulkab.bps.go.id/ ipds@3402/pdf_publikasi/BantulDalam-Angka-2015.pdf.

Basuki, W. (2015). Faktor-faktor penyebab kesepian terhadap tingkat depresi pada lansia penghuni Panti Sosial Tresna Werdha Nirwana Puri Kota Samarinda. eJournal Psikologi, 4(1): 713-730.

Burholt, V. \& Scharf, T. (2014). Poor health and loneliness in later life: The role of depressive symptoms, social resources and rural environments. J Gerontol B 
Psychol Sci Soc Sci, 69(2): 311-324.

Dahlberg, L. \& McKee, K. 2014. Correlates of social and emotional loneliness in older people: Evidence from an English community study. Aging Ment Health, 18(4): 504-514.

Damayanti, Y. \& Sukmono, A.C. (2015). Perbedaan kesepian lansia yang tinggal di Panti Wredha dan di rumah bersama keluarga. Fakultas Keperawatan STIKES Hang Tuah Surabaya, Indonesia. Naskah tidak dipublikasikan.

Irawan, H. (2013). Gangguan Depresi pada Lanjut Usia. CDK-210, 40(11): 815-819.

Sadock, B. J., \& Sadock, V. A. (2010). Concise textbook of clinical psychiatry (2nd edition). (Alih bahasa: Profitasari, Nisa T. M.). Jakarta: Penerbit Buku Kedokteran EGC. (Buku asli terbit 2004).

Kementerian Kesehatan RI. (2016). Profil Kesehatan Indoensia Tahun 2015. Retrieved from http://www.depkes.go.id/ resources/download/pusdatin/profilkesehatan-indonesia/profil-kesehatanIndonesia-2015.pdf.

Kristyaningsih, D. (2011). Hubungan antara dukungan keluarga dengan tingkat depresi pada lansia. Jurnal Keperawatan Indonesia, 1(1).

Kurniasari, N. D. (2014). Faktor-faktor yang berhubungan dengan depresi pada lansia di Dusun Kalimanjung Ambarketawang Gamping Sleman Yogyakarta (Skripsi). Universitas Muhammadiyah Yogyakarta, Indonesia.

Monika, A.D. (2015). Perbedaan tingkat depresi antara lansia yang tinggal di Panti Wredha Dharma Bakti dan yang bersama keluarga di Kelurahan Pajang (Skripsi). Fakultas Kedokteran Universitas Muhammadiyah Surakarta, Jawa Tengah, Indonesia.

Nauli, F. A., Yuliatri, E., \& Savita, R. (2014).
Hubungan tingkat depresi dengan tingkat kemandirian dalam aktivitas sehari-hari pada lansia di wilayah kerja Puskesmas Tembilahan Hulu. Jurnal Keperawatan Soedirman (The Soedirman Journal of Nursing), 9(2): 103-110.

Nurhayati. (2016). Konflik interpersonal dalam interaksi sosial lanjut usia: Studi deskriptif interaksi sosial lansia di Panti Sosial Tresna Werdha Budi Pertiwi Lengkong Bandung (Skripsi). Program Studi Pendidikan Sosiologi, Fakultas Pendidikan IImu Pengetahuan Sosial, Universitas Pendidikan Indonesia, Bandung Indonesia.

Pangulu, Rachmawati, Suratini, S. (2015). Hubungan aktivitas fisik dengan kejadian insomnia pada usia lanjut di Panti Sosial Tresna Wredha Yogyakarta Unit Budi Luhur Kasongan Bantul (Skripsi). STIKES 'Aisyiyah Yogyakarta, Yogyakarta, Indonesia.

Pudjiastuti, N. (2013). Lansia dan PerubahanPerubahan yang Terjadi. Jakarta: Penerbit Buku Kedokteran EGC.

Pusat Data dan Informasi Kemenkes RI. (2013). Gambaran kesehatan lanjut usia di Indonesia. Buletin Jendela Data \& Informasi Kesehatan, 1-18.

Qonitah, N. \& Isfandiari, M. (2015). Hubungan antara IMT dan Kemandirian Fisik dengan Gangguan Mental Emosional pada Lansia. Jurnal Berkala Epidemiologi, 3(1): 1-11.

Sanjaya, A. dan Rusdi, I. (2013). Hubungan interaksi sosial dengan kesepian lansia (Skripsi). Fakultas Keperawatan Universitas Sumatra Utara, Medan, Indonesia.

Septiningsih, D.S. \& Na'imah, T. (2012). Kesepian pada lanjut usia; studi tentang bentuk, faktor pencetus dan strategi koping. Jurnal Psikologi, 11(2): 9.

Setiawan, B. M., Budiningsih T. E., 
Andromeda, A. (2013). Kesepian pada lansia di Panti Werdha Sultan Fatah Demak. Developmental and Clinical Psychology, 2(1): 44-47.

Sugiyanti, N. (2010). Hubungan dukungan sosial dengan perasaan kesepian pada lanjut usia di Padukuhan Kramen Sidoagung Godean Sleman Yogyakarta (Skripsi). Universitas 'Aisyiyah Yogyakarta, Yogyakarta, Indonesia.

Sustyani, R.A., Indriati, \& Supriyadi. (2012). Hubungan antara depresi dengan kejadian insomnia pada lanjut usia di Panti Wredha Harapan Ibu Semarang (Skripsi). Sekolah Tinggi Ilmu Kesehatan Telogorejo, Semarang, Indonesia.

Utomo, T. L. (2013). Hubungan antara faktor somatik, psikososial dan sosiokultural dengan kejadian skizofrenia di Instalasi Rawat Jalan di RSJD Surakarta (Skripsi). Fakultas IImu Kesehatan, Universitas Muhammadiyah Surakarta, Jawa Tengah, Indonesia.

Verawati, K, P. (2015). Kesepian lansia ditinjau dari tempat tinggal (Skripsi). Fakultas Psikologi, Universitas Kristen Satya Wacana, Salatiga, Jawa Tengah, Indonesia.

Wu, Y. \& Zhang, C. (2011). The impact of isolation and loneliness on elderly wellbeing (Skripsi). University of Applied Sciences Novia, Vaasa, Finland. 